\title{
THE USE OF SMARTPHONE AND LEARNING STRATEGIES IN AUTONOMOUS LEARNING
}

\author{
Nurhaeni \\ Universitas Sulawesi Barat \\ E-mail: neni_jahar@yahoo.com \\ Pupung Purnawarman \\ Universitas Pendidikan Indonesia \\ E-mail: ppurnawarman.gmail.com
}

\begin{abstract}
APA Citation: Nurhaeni, \& Purnawarman, P. (2018). The use of smartphone and learning strategies in autonomous learning. Indonesian EFL Journal, 4(1), 43-48. DOI: 10.25134/ieflj.v4i1.797.
\end{abstract}

\begin{abstract}
Rapid penetration of smartphone in students' life currently leads to the extreme influence and addiction of smartphone use in their daily activities (Alexander, 2011; Hough, 2011). Later on, it raises concern about the negative impact of smartphone use towards students' learning performance and achievement (Kibona \& Mgaya, 2015). On the other hand, several studies found that smartphone is a possible learning tool that can be utilized by students to learn on their own, or autonomously (Kim \& Kwon, 2012; White \& Mills, 2014; Woodcock, Middleton, \& Nortcliffe, 2012). Hence, the purpose of this research was to investigate whether or not the smartphone use can influence students' learning strategies in autonomous learning. Both smartphone and autonomous learning share similar principle of independence based on their traits, such as taking control in learning and individuality. The students of Islamic Economy Department that currently enrolled in English class were chosen as the sample of this research. Correlational study was applied with further regression analysis conducted on the collected data. The instruments used in this research were questionnaires and interview. The findings revealed that the use of smartphone influence students' learning strategies. Furthermore, cognitive and social/affective strategies are the strategies that were influenced the most and metacognitive strategies were influenced the least by the use of smartphone in learning English.
\end{abstract}

Keywords: autonomous learning, learning strategies, smartphone use

\section{INTRODUCTION}

Smartphone is one of ICT (Information Communication and Technology) products that gradually penetrates into students' daily activities and becomes part of their life. Yet, the intense penetration rapidly leads to extreme influence of technology, such as social media addiction and strong isolation when forced to unplug from technology (Hough, 2011). According to the infographic research done by HackCollege.com, 57\% of college students use smartphones, $60 \%$ feel addicted to their phone, and $75 \%$ sleep next to their phones (Alexander, 2011). Responding to the significant influence of smartphone on students' life, a number of research have been conducted to integrate smartphone into education field in order to gain the most benefit from it, particularly in language learning (Chu, 2011; Subramaniam \& Harun, 2013). Considering that smartphone is a personal device, students can access it without teachers' instruction. Kim and Kwon (2012) reveal hundreds of smartphone application related to "ESL" that can be accessed by students themselves. Related to students' individual learning, White and Mills (2014) and Woodcock, Middleton, and Nortcliffe (2012) have investigated students' use of smartphones for their individual learning. The studies prove that smartphone offers students with individual learning activity which is strongly related to autonomous learning. In his book, Principles of Language Learning and Teaching, Brown (2000, p. 130) 


\section{Nurhaeni \& Pupung Purnawarman}

The use of smartphone and learning strategies in autonomous learning

points out that Wenden (1985) was among the first to assert that learner strategies are the key to learner autonomy and he believes that one of the most important goals of language teaching should be the facilitation of that autonomy. Cited in Benson (2011, p. 97), Oxford (1990) splits learning strategies into direct and indirect strategies. Direct strategies defined as something related to mental processing of the target language, while indirect strategies include the aspects which support learning through "focusing, planning, evaluating, seeking opportunities, controlling anxiety, increasing cooperation and empathy, and other means." The Indirect strategies then divided into three categories, namely metacognitive, social and affective. The indirect strategies perceived as contained of the potential components of autonomy in language learning since the strategies concerned with control over the learning process rather than control over language or learning materials.

Further explanation related to the indirect strategies which are associated with autonomous learning displayed in three major categories of learning strategies schema proposed by O'Malley and Chamot (1990, p. 44), which are cognitive, metacognitive, social/affective strategies. Cognitive strategies related to the information obtained and how to manipulate it while metacognitive strategies cover the whole process from planning, monitoring, and evaluation, and social/affective strategies refer to students' ability to control themselves in learning and their interaction with others during the process of learning.

Smartphones have developed considerably, then becoming increasingly common place following the release of Apple's iPhone in 2007 (Woodcock, Middleton, \& Nortcliffe, 2012). The revolution of mobile learning related to the smartphone development is indicated through a huge number of apps that are available from different apps stores. In May 2013, 50 billion apps downloaded from the iTunes App store. This fact displays the rich of available options of language apps (Rossel-Agullar, 2014). Smartphones can be customized with new software, and the variety of these programs are increasing. The social communication platforms (like Facebook, Twitter, Instagram, WhatsApp, etc.), GPS functions and games are especially popular (Kibona \& Mgaya, 2015).

Hence, the function of smartphone is wider and more versatile to meet different purposes of the users, including education purposes. It is in line with the statement by Chu (2011) that based on the research data, smartphone applications are not only commercially successful but also pedagogically beneficial. The main reason for students to choose mobile learning via smartphone is because of the functionality. The efficient learning functions are perceived to be possible through the use of the technology. Zilber (2013) strengthens the notion of smartphone functionality for learning by stating that smartphone is often an individual's sole communication and computing platform which make it has the attributes that make them well suited to the delivery of certain kinds of English language learning and practice.

\section{Numerous advantages offered by} smartphones to support autonomous learning are indicated by Kim and Kwon (2012), who explain that mobile learning provides students with some advantages to facilitate productivity and effectiveness by giving them the opportunity to be more flexible, accessible, and to personalize their learning activities. Moreover, through the use of mobile learning, the sense of individuality, community, and ubiquitousness in learning can be developed and give the students the enjoyment to have a particular amount of freedom and independence. The principle of freedom and independence given by the use of smartphone in learning is similar to the principle explained in autonomous learning. Promoting autonomous learning through the use of mobile learning can be possible since mobile learning creates a space for students to adjust the learning material and activity to their own availability. Godwin-Jones (2011) points out that for students, mobile devices integrate reallife interests and academic roles. If learner autonomy is about personal choice, then mobile should serve as an ideal enabler. 
Hence, this study explored the role of smartphone use on learning strategies in autonomous learning. This study specifically investigated the influence of smartphone use on learning strategies in autonomous learning amongst students in terms of English learning purposes, and how the learning strategies (metacognitive, cognitive, and social/affective) are applied during the use of smartphone in learning English.

\section{METHOD}

The correlational design was initially applied to answer the problem identified in this research. Correlational research methods are used to assess relationships and patterns of relationship among variables in a single group of subjects (Ary, et al., 2010). Afterwards, the correlational design finding was supported by the regression analysis to reveal the influence of smartphone use towards students' autonomous learning strategies. Furthermore, participants' verbal interview data that had been collected for further exploration was also analyzed to strengthen the findings.

There were two types of instrument applied in this research. The first is questionnaires and second is interview sheet. The participants fulfilled questionnaires related to both the learning strategies in autonomous learning and their activities in using smartphones in learning English. The questionnaire of learning strategy in autonomous learning was adapted from a thesis written by White (1993). The reason of the adaptation from the particular thesis was because of the similarity on the investigated variables. Also, the second questionnaire which was intended to measure the use of smartphone in English learning was established based on the explanation of five properties of mobile devices which provide the unique educational affordance conveyed by Klopfer and Squire (2008). Along with the questionnaires, there was an interview held for the chosen participants in order to confirm and explore further on how they applied the metacognitive, cognitive, and social/affective strategy during the use of smartphone in learning English.

The participants of this research were the students of Islamic Economy Department in a university in Bandung. The Islamic Economy Department was chosen since it was a relatively new department, and one of the fundamental principles was a strong mastery of foreign languages by the students. Hence, the students of the department obliged to enroll in a basic English class at the particular semester. There were two English classes for this semester with 65 students of all. Looking on the number of students, the sample was then decided to be saturated sampling. It means that all of the population taken as the sample $(\mathrm{N}=65)$.

\section{RESULTS AND DISCUSSION}

The data collected through the instruments display a moderate relationship between smartphone use in learning English and learning strategies in autonomous learning. It was proven by the correlation coefficient of 0,612. By relating the data obtained through the questionnaire and interview, it is perceived that the students mostly access the smartphone for searching information and having communication for general purposes. In terms of learning English, majority of students indicated learning English through smartphone applications, accessed the materials through various sources in smartphone, and used smartphone for English tasks related purposes.

Table 1. Rank Spearman and Pearson correlational analysis

\begin{tabular}{llrrr} 
& Variables & \multicolumn{2}{c}{ Correlation } & Note* \\
\cline { 3 - 3 } & & Spearman & Pearson & \\
Smartphone Use & Learning Strategies & 0.612 & 0.612 & Moderate \\
\hline
\end{tabular}

*The classification is based on Muijs (2004: 145)

Table 2. Regression Analysis of smartphone use on learning strategies

\begin{tabular}{ccccc}
\hline Regression & $\mathbf{t}_{\text {count }}$ & $\mathbf{t}_{\text {table }}$ & Signifance & $\mathbf{R}^{\mathbf{2}}$ \\
\hline $\mathrm{X} \longrightarrow \mathrm{Y}$ & 6.144 & 1.998 & Significant & 0.375 \\
\hline
\end{tabular}


The use of smartphone and learning strategies in autonomous learning

Besides the correlation analysis, further regression analysis conducted and the coefficient of determination result, which is 0,375 , indicates that there is an influence of smartphone use in learning English towards students' learning strategies in autonomous learning. The students stated that they used smartphone in learning English because it is helpful, fast, and rich of source. It gives them opportunities to learn English in various ways. They were able to use it in learning English using different types of applications, such as using music player to listen to English song, or accessing audio dictionary for English listening practice.
The ubiquitousness of smartphone is repeatedly insisted by the participants in this research as one of the huge advantages for learning which is related to several previous studies about smartphone use (Miangah \& Nezarat, 2012; Zilber, 2013). The findings reveal the advantages offered by smartphone for learning English such as fast, easy, and providing fruitful information for the students. This description gives us a hint on how learning by using smartphone as one of technology products can help the students beyond the classroom or formal session and flexible for various situations (Reinders \& White, 2011).

Table 3. Rank Spearman and Pearson correlation analysis

\begin{tabular}{|c|c|c|c|c|}
\hline Variable & $\begin{array}{c}\text { Sub -variables } \\
\text { (learning strategies) }\end{array}$ & $\begin{array}{r}\text { Cor } \\
\text { Spearman }\end{array}$ & $\begin{array}{l}\text { elation } \\
\text { Pearson }\end{array}$ & Note* \\
\hline \multirow{3}{*}{$\begin{array}{l}\text { Smartphone } \\
\text { use }\end{array}$} & Cognitive strategies & 0.523 & 0.564 & Moderate \\
\hline & Metacognitive strategies & 0.485 & 0.463 & Modest \\
\hline & Social/Affective strategies & 0.573 & 0.564 & Moderate \\
\hline
\end{tabular}

*The classification is based on Muijs (2004, p. 145)

Table 4. Regression analysis of smartphone use on metacognitive, cognitive, and social/affective strategies

\begin{tabular}{ccclc}
\hline Regression & $\mathbf{t}_{\text {count }}$ & ttable & Signifance & $\mathbf{R}^{\mathbf{2}}$ \\
\hline $\mathrm{X} \longrightarrow \mathrm{Y} 1$ & 5.420 & 1.998 & Significant & 0.318 \\
$\mathrm{X} \longrightarrow \mathrm{Y} 2$ & 4.147 & 1.998 & Significant & 0.214 \\
$\mathrm{X} \longrightarrow \mathrm{Y} 3$ & 5.423 & 1.998 & Significant & 0.318 \\
\hline
\end{tabular}

The statistical analysis reveals that metacognitive strategies are detected to have modest correlation with the use of smartphone in learning English since the correlation coefficient value are 0,485 and 0,463 . Further, the regression analysis result shows 0,214 coefficients of determination. It can be perceived that without considering other factors, the use of smartphone in learning English influence students' metacognitive strategies up to $21 \%$.

Among all the listed strategies included as parts of metacognitive, self-management and prioritizing become the most frequent strategies applied by the students. The students applied both strategies when they searched for particular applications in smartphones and did the selection before downloading the applications. The selection process is conducted based on the students' interests. On the other hand, the correlation analysis of smartphone use and students' cognitive strategies show 0,523 and 0,564 coefficient of correlation which indicated as moderate correlation. The regression analysis of smartphone use and cognitive strategies is resulted on 0,318 coefficient of determination, which is the same with cognitive strategies. Both correlation and regression analysis of smartphone use and social/affective strategies are indicated higher than metacognitive strategies.

The cognitive strategies as the strategies that get influenced more by the use of smartphone in learning English indicate several particular strategies applied by the 
students. In using smartphones in learning English, the students, mostly applied the strategies of resourcing, transferring, and translating from Indonesian to English. The resourcing strategy is identified since the students utilized applications in smartphone to replace the function of other material, for instance, electronic dictionary can function like the hard copy dictionary. The students also do re-checking on their English work after doing the task using a smartphone, which is indicated as transfer strategy. Furthermore, doing translation whether from, or to English are the most frequent strategies applied by the students during their English learning activity using smartphone.

The social/affective strategies were indicated to have moderate correlation with the use of smartphone in learning English. The correlation coefficient of smartphone use in learning English and social/affective strategies are 0,573 and 0,564 . They are higher compared to the correlation coefficient of metacognitive strategies and cognitive strategies. Yet, the regression analysis of smartphone use and social/affective strategies gains 0,318 coefficient of determination, which is the same with cognitive strategies.

In social/affective strategies, students mostly applied the co-operation strategy. The strategies are defined through their activities of posting status in English on their social media. Also, the students sometimes do chatting activity in English with others, whether they friends or someone they only know through the social media. Besides, the smartphone use in supporting English learning activity also give students more selfconfidence in their learning.

As stated by the students, in terms of learning English, mostly the smartphone is used for translating difficult words, browsing materials, and posting on social media. Those activities have been investigated by KukulskaHulme in Kurtz (2012), as the new activities emerging during the period 2005-2010. Social/community interaction and mobile internet access that related to the strategies applied by the students are included in the emerging activities. It shows us that the activities of smartphone use for general purposes also reflected on the use of smartphone for learning English, and related to cognitive and social/affective strategies.

Metacognitive strategies are indicated as the least strategies affected by the use of smartphone in learning English. As Guo (2012) defines that metacognitive concern on the individual conscious control of cognitive strategies, it rarely indicated in this research since the students admitted that they tend to not applying much control of their learning strategies during the use of smartphone in learning English.

\section{CONCLUSION}

The students admitted that the use of smartphone in learning English has an influence to shape their learning strategies activities in autonomus learning. They perceive the smartphone functions as fast, easy, and fruitful in helping them learning English. Mostly, the difficulties faced by the students during the smartphone use in learning English related to technical factors and their own internal initiative. Among the three strategies investigated in this research, cognitive and social/affective strategies indicated to be influenced the most by the use of smartphone in learning English. On the other hand, metacognitive strategies are proven to get the least influenced by the use of smartphone in learning English.

The students apply metacognitive strategies while using smartphones in learning English by accessing the applications based on their need and interests, which is closer to the strategy of prioritizing. Related to cognitive strategies, students tend to mostly apply translation strategies both to and from English, while using smartphones in their English learning. In the meantime, for social/affective strategies, students use smartphone for their English learning to communicate with others in the target language and to assure themselves in the process of using English for their needs.

\section{REFERENCES}

Alexander. A. (2011). How reliant are college students on smartphones? Retrieved from 


\section{Nurhaeni \& Pupung Purnawarman}

The use of smartphone and learning strategies in autonomous learning

http://ansonalex.com/technology/how-reliant-arecollege-students-on-smartphones-infographic/.

Ary, D., Jacobs, L., Sorensen, C., \& Razavieh, A. (2010). Introduction to research in education. Belmont, CA: Wadsworth Cengage Learning.

Benson, P. (2011). Teaching and researching autonomy. New York, NY: Routledge, Taylor \& Francis Group.

Brown, H. D. (2000). Principles of language learning and teaching. White Plains, NY: Addison Wesley Longman.

Chu, H. (2011). The effect of the features of smart phone vocabulary applications on Korean college students' satisfaction and continued use.

Multimedia -Assisted Language Learning, 14(2), 91-112. Retrieved from

http://kmjournal.bada.cc/wpcontent/uploads/2013/05/14-2-4Chu.pdf.

Godwin-Jones, R. (2011). Emerging technologies: Mobile apps for language learning. Language Learning \& Technology, 15(2), 2-11.

Guo, H. (2012). An empirical study on the relation between meta-cognitive strategies and listening autonomous learning ability. Theory and Practice in Language Studies, 2(11), 2446-2451. DOI:10.4304/tpls.2.11.2446-2451.

Hough, A. (2011). Student 'addiction' to technology 'similar to drug cravings', study finds. RetrievedFromhttp://www.telegraph.co.uk/technol ogy/news/8436831/Student-addiction-totechnology-similar-to-drug-cravings-studyfinds.html.

Kibona, L., \& Mgaya, G. (2015). Smartphones' effects on academic performance of higher learning students: A case of Ruaha Catholic University Iringa, Tanzania. Journal of Multidisciplinary Engineering Science and Technology (JMEST), 2(4), 777-784.

Kim, H., \& Kwon, Y. (2012). Exploring smartphone applications for effective mobile-assisted language learning. Multimedia-Assisted Language Learning, 15(1), 31-57. Retrieved from http://kmjournal.bada.cc/wpcontent/uploads/2013/05/15-1-2Kim.pdf.

Klopfer, E., \& Squire, K. (2008). Environmental detectives: The development of an augmented reality platform for environmental simulations. Educational Technology Research and Development, 56(2), 203-228.
Kurtz, L. (2012). Learning from twenty-first century second language learners: A case study in smartphone use of language learners (A Thesis, Iowa State University, 2012). Retrieved from http://lib.dr.iastate.edu/etd/12669/.

Miangah, T. M., \& Nezarat, A. (2012). Mobile-assisted language learning. International Journal of Distributed and Parallel Systems (IJDPS), 3(1), 309-319.

O'Malley, J. M., \& Chamot, A. U. (1990). Learning strategies in second language acquisition. New York, NY: Cambridge University Press.

Reinders, H., \& White, C. (2011). Learner autonomy and new learning environments. Special Issue on Learner Autonomy and New Learning Environments, 15(3), 1-3.

Rossel-Agullar, F. (2014). How smartphone apps are revolutionizing language learning. Retrieved February 21st , 2015 from http://theconversation.com/how-smartphone-appsare-revolutionising-language-learning-25165.

Subramaniam, G., \& Harun, R. (2013). Adoption of mobile technology in higher education: Students' perceptions of English language learning using smartphones. International Journal of Asian Social Science, 3(9), 2084-2089. Retrieved from http://www.aessweb.com/pdf-files/ijass-si-3(9)2084-2089.pdf.

White, C. (1993). Metacognitive, cognitive, social and affective strategy use in foreign language learning: A comparative study (A Thesis, Massey University).

White, J., \& Mills, D. (2014). Examining attitudes towards and usage of smartphone technology among Japanese university students studying EFL. CALL-EJ, 15(2), 1-15.Retrieved from http://callej.org/journal/152/White_Mills_2014.pdf.

Woodcock, B., Middleton, A., \& Nortcliffe, A. (2012). Considering the smartphone learner: An investigation into student interest in the use of personal technology to enhance their learning. Student Engagement and Experience Journal, 1(1), 1-15. DOI: 10.7190/seej.v1i1.38.

Zilber, J. (2013). Smartphone apps for ESL: Finding the Wheat Amidst the Chaff. CONTACT Magazine, pp. 15-21. 